\title{
Assessment of the mechanical properties of glass ionomer cements for orthodontic cementation
}

\author{
Marcel M. Farret ${ }^{1}$, Eduardo Martinelli de Lima², Eduardo Gonçalves Mota ${ }^{3}$, Hugo Mitsuo S. Oshima ${ }^{4}$, \\ Gabriela Maguilnik ${ }^{5}$ Patrícia Alves Scheid ${ }^{6}$
}

\begin{abstract}
Objective: To evaluate the mechanical properties of three glass ionomers cements (GICs) used for band cementation in Orthodontics. Methods: Two conventional glass ionomers (Ketac Cem Easy mix/3M-ESPE and Meron/Voco) and one resin modified glass ionomer (Multi-cure Glass ionomer/3M-Unitek) were selected. For the compressive strength and diametral tensile strength tests, 12 specimens were made of each material. For the microhardness test 15 specimens were made of each material and for the shear bond strength tests 45 bovine permanent incisors were used mounted in a self-cure acrylic resin. Then, band segments with a welded bracket were cemented on the buccal surface of the crowns. For the mechanical tests of compressive and diametral tensile strength and shear bond strength a universal testing machine was used with a crosshead speed of 1,0 mm/min and for the Vickers microhardness analysis tests a Microdurometer was used with $200 \mathrm{~g}$ of load during 15 seconds. The results were submitted to statistical analysis through ANOVA complemented by Tukey's test at a significance level of 5\%. Results: The results shown that the Multi-Cure Glass Ionomer presented higher diametral tensile strength $(\mathrm{p}<0.01)$ and compressive strength greater than conventional GICs $(\mathrm{p}=0.08)$. Moreover, Ketac Cem showed significant less microhardness $(\mathrm{p}<0.01)$. Conclusion: The resin-modified glass ionomer cement showed high mechanical properties, compared to the conventional glass ionomer cements, which had few differences between them.
\end{abstract}

Keywords: Glass ionomer cements. Dental material. Cementation. Orthodontics.

Objetivo: avaliar as propriedades mecânicas de três cimentos de ionômero de vidro (CIVs) utilizados para cimentação de anéis ortodônticos. Métodos: foram utilizados dois CIVs convencionais (Ketac Cem Easy mix/3M-ESPE e Meron/Voco) e um CIV modificado por resina (Multi-Cure Glass ionomer/3M-Unitek). Para os testes de resistência à compressão e tração diametral, foram confeccionados 12 corpos de prova de cada material. Para os testes de microdureza, foram confeccionados 15 corpos de prova de cada material; para os testes de resistência de união ao cisalhamento, foram utilizados 45 dentes bovinos incluídos em resina acrílica, sobre os quais foi cimentada uma lâmina de anel ortodôntico com braquete soldado a ela para realização dos ensaios. Para os testes de compressão, tração diametral e cisalhamento, foi utilizada uma máquina universal de ensaios a uma velocidade de lmm/min; para os testes de microdureza Vickers, foi utilizado um microdurômetro com $200 \mathrm{~g}$ de carga durante 15 segundos. Os resultados foram submetidos à análise estatística ANOVA, complementada pelo teste de Tukey ao nível de significância de $5 \%$. Resultados: os resultados demonstraram que o Multi-Cure Glass Ionomer apresentou resistência à tração diametral significativamente maior $(\mathrm{p}<0,01)$ e maior resistência à compressão $(\mathrm{p}=0,08)$ em relação aos CIVs convencionais. Além disso, o Ketac Cem apresentou microdureza significativamente maior que os demais materiais $(p<0,01)$. Conclusão: $o$ CIV modificado por resina apresentou propriedades mecânicas superiores às dos CIVs convencionais, que, por sua vez, apresentaram poucas diferenças entre si.

Palavras-chave: Cimentos de ionômero de vidro. Materiais dentários. Cimentação. Ortodontia.

${ }^{1}$ Specialist, MSc and PhD in Orthodontics, PUCRS.

${ }^{2} \mathrm{MSc}$ and $\mathrm{PhD}$ in Orthodontics, UFRJ. Professor, PUCRS.

${ }^{3} \mathrm{MSc}$ and $\mathrm{PhD}$ in Dental Materials, PUCRS. Professor, PUCRS.

${ }^{4} \mathrm{MSc}$ and $\mathrm{PhD}$ in Dental Materials, FOP/Campinas. Professor, PUCRS.

${ }^{5}$ Specialist in Orthodontics, PUCRS.

${ }^{6}$ Specialist in Restorative Dentistry, UFRGS. MSc in Dental Materials, PUCRS.

Submitted: December 9, 2009 - Revised and accepted: December 29, 2010
How to cite this article: Farret MM, Lima EM, Mota EG, Oshima HMS, Maguilnik G, Scheid PA. Assessment of the mechanical properties of glass ionomer cements for orthodontic cementation. Dental Press J Orthod. 2012 Nov-Dec;17(6):154-9.

» The author reports no commercial, proprietary or financial interest in the products or companies described in this article.

Contact address: Marcel Marchiori Farret

Rua Floriano Peixoto, 1000/113 - CEP: 97.015-370 - Santa Maria/RS -Brazil

E-mail: marcelfarret@yahoo.com.br 


\section{INTRODUCTION}

Conventional glass ionomer cements (GICs) are widely used in orthodontics and is usually the material of choice for bands and auxiliary appliances cementation. ${ }^{2,6,12-15,19}$ Several characteristics encourage the use of these materials as biocompatibility, chemical union to enamel and constant release of fluoride. ${ }^{2-6,16,21,25,27}$ Specifically in use with orthodontic bands, these features become very important to reduce the incidence of caries and periodontal diseases and provide appropriate union strength between teeth and bands..$^{9,10,13,18,23,24}$

However, the conventional GICs have disadvantages which can compromise its mechanical performance, such as the susceptibility to moisture during the initial setting reaction, which may extend up to one hour. ${ }^{1,4,5,7,20}$ In order to eliminate these deficiencies, some years ago resin-modified glass ionomers materials were developed, which have the acid-base reaction complemented by a photopolymerization reaction, reducing the time of the setting process and exposure to moisture and thus avoiding excessive water uptake of the oral cavity. ${ }^{7,8,20,26}$

Many in vitro studies have already analyzed the mechanical properties of conventional GICs and resin-modified GICs used for orthodontic purposes, however, few studies have associated shear bond strength tests and some doubt still exists regarding the performance of these materials in similar situations to those found in the oral environment. Therefore, the aim of this study was to evaluate two conventional GICs and a resin-modified GIC, comparing the mechanical properties of compressive strength and diametral tensile strength, microhardness and shear bond strength. The first null hypothesis (1) is that there is no differ- ence between the mechanical properties of both conventional GICs and the second null hypothesis (2) is that there is no difference between the conventional GICs and resin-modified GIC.

\section{MATERIAL AND METHODS Material}

Two conventional glass ionomer cements were used in the study: Meron ${ }^{\circledR}$ (Voco, Germany) batch 1090005093 and Ketac Cem easy mix $^{\circledR}$ (3M/ESPE, USA) batch 370919 and a resin-modified glass ionomer Multi-cure Glass Ionomer ${ }^{\circledR}$ (3M/Unitek, USA) batch 8GG/8EU 2009-08.

For the compressive strength tests 12 cylindrical specimens of each material with dimensions of $3 \times 6 \mathrm{~mm}$ were made with a metallic Teflon mold (Fig 1A). For the diametral tensile strength tests, 12 cylindrical specimens with dimensions of $6 \times 3 \mathrm{~mm}$ for each material were made with a silicone matrix (Fig 1B). For microhardness tests 15 cylindrical specimens with dimensions of $3 \times 6 \mathrm{~mm}$ were made. The materials were manipulated according to the manufacturer's instructions on a glass plate with the aid of a plastic spatula. Subsequently the material was injected into the matrix and another glass plate was positioned with pressure over the matrix to remove material excess. For the conventional glass-ionomer cements the conventional setting time of 10 minutes was anticipated whereas the resin-modified GIC was photopolymerized for 40 seconds with halogen light source Optilux ${ }^{\circledR}\left(3 \mathrm{M} /\right.$ Unitek - USA) set at $400 \mathrm{mw} / \mathrm{cm}^{2}$. After polymerization, all specimens were placed in a container with $100 \%$ relative humidity for an hour and then were immersed in distilled water at $37^{\circ} \mathrm{C}$ for 24 hours before mechanical testing.
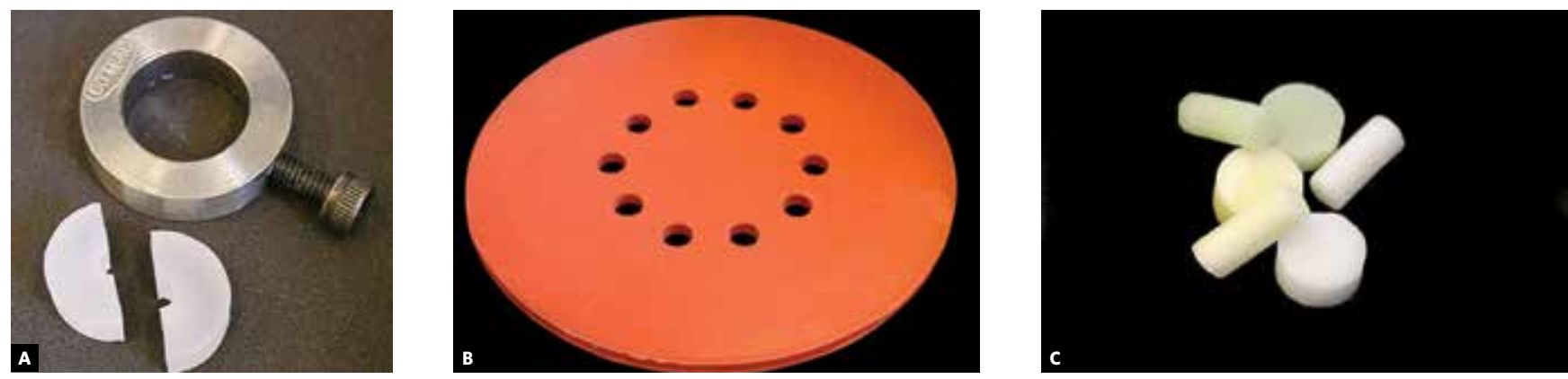

Figure 1 - Matrixes for specimen manufacture for compressive strength test (A), diametral tensile strength test (B) and specimens after removal from the matrixes $(\mathbf{C})$ 
For the shear strength tests 45 permanent bovine incisors were selected with similar buccal enamel surface characteristics, with no fractures and without deep grooves or stains. With the aid of a diamond disc, teeth were sectioned at the level of the cervical third of the root and with a diamond bur, retention grooves were prepared on the mesial and distal surfaces. The crowns were placed on a slide wax so that the central region of the buccal surface was parallel to the ground. In this position, the crowns were fixed with wax and PVC tubes measuring 20 x $20 \mathrm{~mm}$ were placed over the wax with the crown centralized and self-cured acrylic resin was poured into the tubes. After acrylic polymerization the resin specimens were cleaned with $\mathrm{Va}$ poretto ${ }^{\circledR}$ to remove wax excess and so the specimens were ready for cementation procedures (Fig 2).

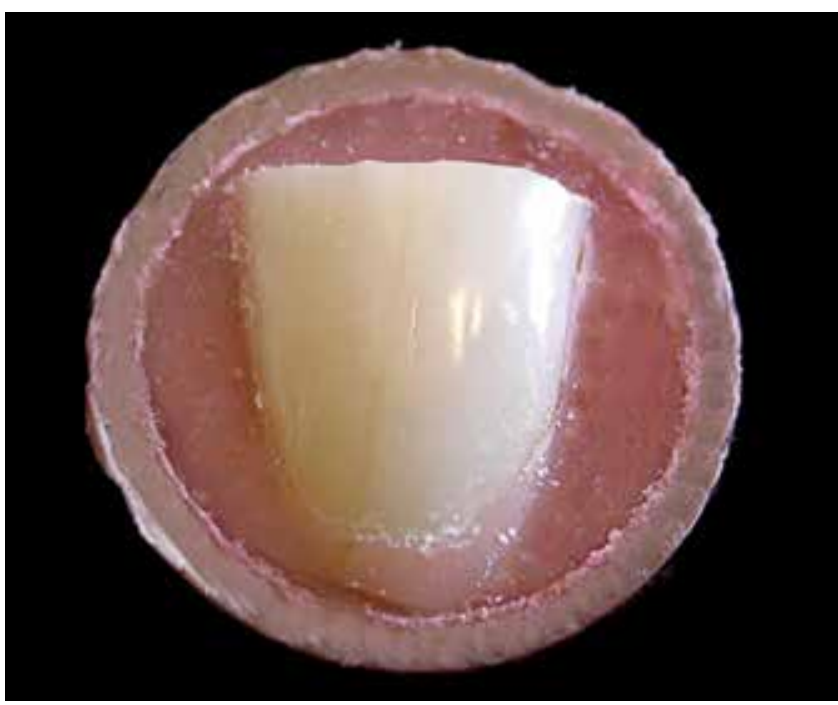

Figure 2 - Bovine tooth sectioned at the cervical third of the root and at the incisal third of the crown and included in acrylic resin.
For the cementation 45 band strips segments were used measuring 10 × $5 \mathrm{~mm}$ (Morelli, Sorocaba SP) on which 45 molar brackets (Morelli, Sorocaba / SP) were welded, all with three welding points (Figs 3A and B). Prophylaxis with pumice and rubber cup was performed on the labial surface and the segments were cemented to these surfaces with each of three different GICs (Fig 3C). After 10 minutes the samples were also placed in a container with $100 \%$ relative humidity for an hour and then immersed in distilled water at $37^{\circ} \mathrm{C}$ for 24 hours.

For compressive strength and diametral tensile strength tests a universal testing machine Emic Dl 2000 (Emic, São José dos Pinhais / PR) was used with the crosshead speed of $1 \mathrm{~mm} / \mathrm{min}$. The maximum strength values prior to failure were recorded and stored by the software Mtest ${ }^{\circledR}$ and submitted to the following equation:

\section{» Compressive strength $=4 \mathrm{~F} / \pi \mathrm{d}^{2}$}

» Diametral tensile strength $=\mathbf{2 F} / \boldsymbol{\pi d h}$

» Where: $\mathrm{F}$ = Maximum strength at the moment of rupture;

$\mathrm{d}$ = Diameter of the specimen; $\mathrm{h}=$ Height of the specimen.

For the shear strength test the universal testing machine Emic DL 2000 was also used, using a matrix with a loading chisel with $2 \mathrm{~mm}$ thickness in contact with the bracket, with a crosshead speed of $1 \mathrm{~mm} / \mathrm{min}$ (Fig 4). The maximum strength was recorded in Newtons $(\mathrm{N})$ at the time of rupture and converted into MPa using the software Mtest ${ }^{\circledR}$.

For the microhardness test the Micro Hardness Tester - HMV ${ }^{\circledR}$ (Shimadzu, JP) was used with a load of $200 \mathrm{~g}$ during 15 seconds and the Vickers hardness measurement pattern for all analyses was the standard used.
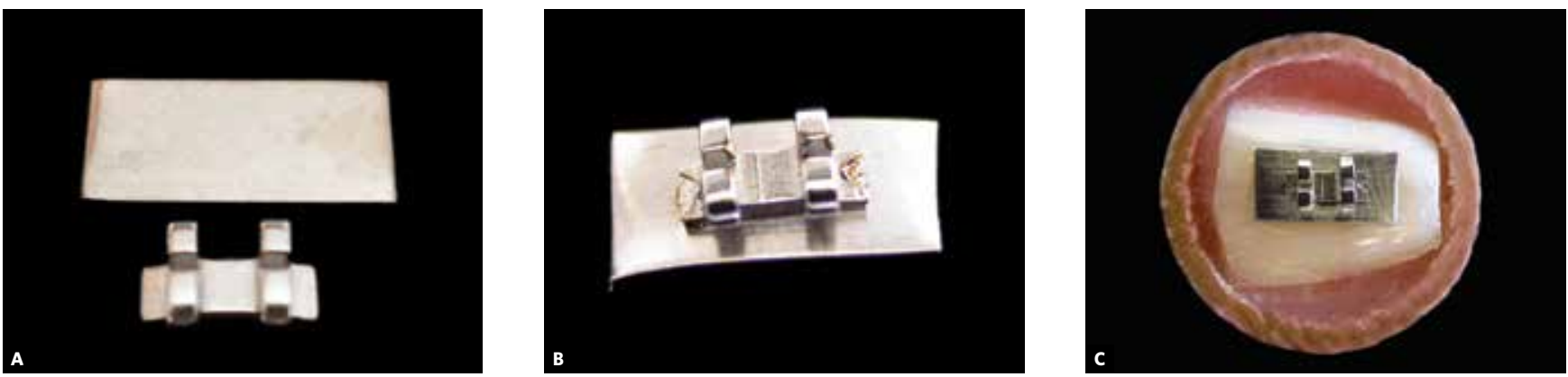

Figure 3 - Metal band strip and bracket used for cementation (A), bracket welded over the band strip (B); band strip cemented to the buccal surface of the crown (C). 


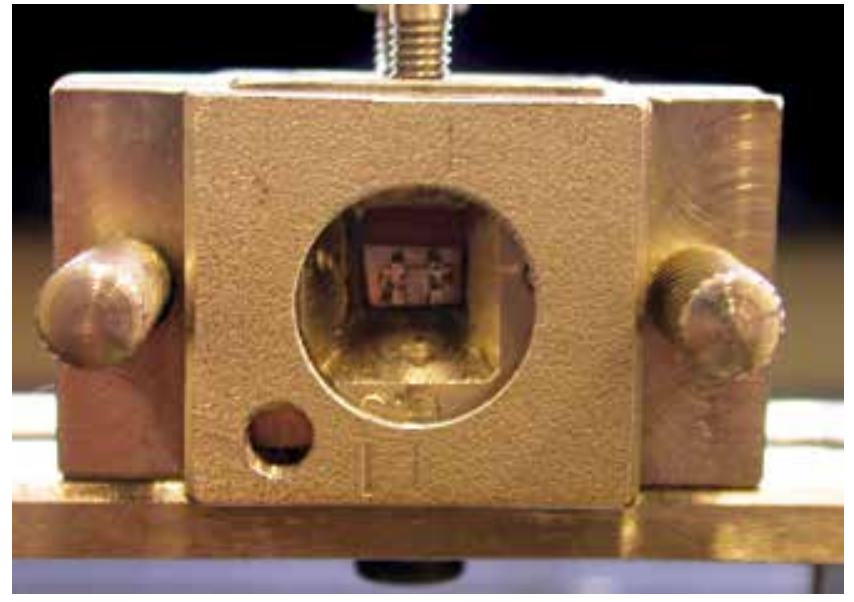

Figure 4 - Specimen positioned in matrix with a loading chisel with $2 \mathrm{~mm}$ thickness for the shear strength tests.

Table 1 - Means, Standard deviation and analysis of variance, complemented by the Tukey's multiple comparison test comparing three groups among them for all the mechanical properties analyzed.

\begin{tabular}{|ccccc}
\hline Test & Group & Mean & $\begin{array}{c}\text { Standard } \\
\text { deviation }\end{array}$ & p \\
\hline \multirow{2}{*}{$\begin{array}{c}\text { Shear bond } \\
\text { strength }\end{array}$} & Meron & 0.50 & 0.29 & \\
& Ketac Cem & 0.51 & 0.27 & 0.30 \\
& Multi-Cure & 0.64 & 0.28 & \\
& Meron & 38.90 & 16.42 & \\
Compressive & Ketac Cem & 52.05 & 19.23 & 0.08 \\
strength & Multi-Cure & 53.08 & 14.05 & \\
& Meron & $6.33^{\mathrm{A}}$ & 2.37 & \\
Diametral tensile & Ketac Cem & $7.53^{\mathrm{A}}$ & 2.01 & $0.00^{\star}$ \\
Strength & Multi-Cure & $16.56^{\mathrm{B}}$ & 2.12 & \\
& Meron & $35.16^{\mathrm{A}}$ & 5.97 & \\
& Ketac Cem & $75.88^{\mathrm{B}}$ & 11.55 & $0.00^{\star}$ \\
\hline \multirow{2}{*}{ Microhardness } & Multi-Cure & $31.89^{\mathrm{A}}$ & 7.54 & \\
\hline
\end{tabular}

* Significant difference $p<0.05$. Means followed by same letter do not differ among them.

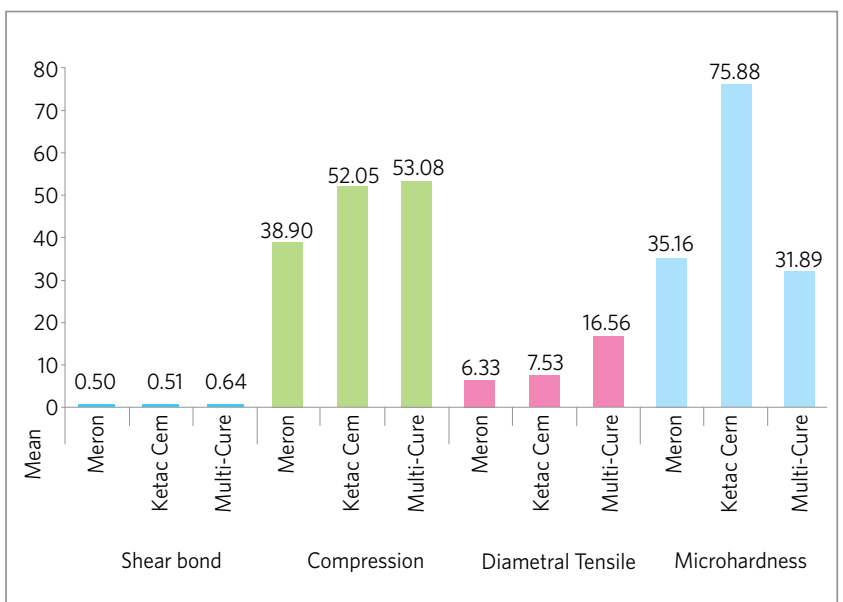

Figure 5 - Comparison among groups for each of the properties analyzed.

\section{Statistical analysis}

The results were statistically analyzed by SPSS version 14.0. For comparison among materials for each mechanical test, analysis of variance (ANOVA) was used, complemented by the Tukey's multiple comparison test, at the maximum level of significance of $5 \%$.

\section{RESULTS}

The results of statistical analysis of the four mechanical properties tested are shown in Table 1 and Figure 5.

The results showed that the resin-modified GIC showed the highest values of diametral tensile strength with a significant difference for the others $(\mathrm{p}<0.01)$. The conventional GIC Ketac Cem easy mix showed the lowest microhardness values with significant difference in comparison to other materials ( $<$ 0.01). Moreover, the GIC Meron had lower compressive strength values, however, with no significant difference $(p=0.08)$.

Considering those results, we find that the two null hypotheses ( 1 and 2) were rejected because there were significant differences among all analyzed materials.

\section{DISCUSSION}

The analysis of the compressive strength, diametral tensile strength and microhardness are essential for verification and comparison of mechanical properties of different dental materials, and may infer what material is best suitable to perform clinical functions, resisting to the masticatory forces, wear and application of orthodontic forces. ${ }^{2,3,17,21,22,28}$ Furthermore, whenever possible it is interesting to associate a test such as shear bond strength to simulate orthodontic treatment and oral environment for checking the performance of a material under similar conditions., ${ }^{1,5,9,11-15}$ In this context, this study included the analysis of four mechanical properties, aiming to determine which of these three materials is most suitable for the cementation of orthodontic bands.

The susceptibility of conventional GICs to moisture substantially influences the mechanical properties of materials. ${ }^{7,20}$ The setting process may last a few hours, however, there is no possibility that this period is expected during the clinical treatment of patients. Usually, professionals wait 5-10 minutes, because this time is supplied as enough by the manu- 
facturers. To simulate the clinical situation, we use the time of 10 minutes post manipulation as standard, prior to placement in an environment with $100 \%$ humidity for the first phase of setting.

Considering the tests, it was found that the resin-modified GIC showed better mechanical properties than other materials in all tests, except by microhardness. These findings are in accordance with other authors who have observed better mechanical properties of this type of material in comparison with conventional GICs. ${ }^{5,12-15,23,24}$ The inclusion of resinous components such as HEMA and Bis-GMA in resin-modified GICs may be consider as responsible for better mechanical properties of these materials. ${ }^{20,26}$ Furthermore, these materials are light cured, which reduces the total setting time and prevents larger exposure to moisture. , $^{8,12,15,23,24}$

The conventional glass ionomer cements showed similar results and only the microhardness for Meron was significantly higher than Ketac Cem. Unlike these results, Aguiar et $\mathrm{al}^{2}$ observed better mechanical properties of conventional GIC Ketac Cem in comparison to Meron, however, these authors did not analyze the microhardness of the materials.

In the analysis of shear bond strength, Multi-Cure Glass Ionomer showed higher values than others, however, with no significant difference. Similar results were already observed by Weissheimer et al. ${ }^{23,24}$ These materials have no chemical union to the metal, so these results may be explained for the greater mechanical imbrication presented by these materials..$^{5,12,13}$ In the initial proposition of the study, the analysis of cement remnant on the enamel surface after the shear test would be performed. However, all specimens showed $100 \%$ of GIC remnant on the enamel, showing the largest union strength at the interface cement/enamel and low union strength with the metal. As an alternative, several authors proposed sandblasting with aluminum oxide of the inner surface of bands as a way to obtain higher imbrication and higher mechanical union strength to the bands..$^{12-15,23,24}$

These results show that the resin-modified GIC has better mechanical properties compared to conventional GICs. However, results of shear bond strengths were similar among the three materials, possibly indicating that they have similar clinical performance, for use in orthodontics. For a further specific analysis of these materials other mechanical in vitro tests are indicated such as the flexural strength test, abrasion resistance and fatigue resistance test. Moreover, there is the possibility of testing the shear strength in extracted third molars, with tailor made bands, trying to represent more accurately the situation of orthodontic practice.

\section{CONCLUSION}

Considering the results obtained, it may be stated that:

» The resin-modified glass ionomer cement showed better mechanical properties.

» The conventional glass ionomer cements have similar mechanical properties.

» In shear strength tests, the three materials showed similar results. 


\section{REFERENCES}

1. Aggarwal M, Foley FT, Rix D. A comparison of shear-peel band strengths of 5 orthodontic cements. Angle Orthod. 2000;70(4):308-16.

2. Aguiar DA, Silveira MR, Ritter DE, Locks A, Calvo MCM. Avaliação das propriedades mecânicas de quatro cimentos de ionômero de vidro convencionais utilizados na cimentação de bandas ortodônticas. Rev Dental Press Ortod Ortop Facial. 2008;13(3):104-11.

3. Bresciani E, Barata TJE, Fagundes TC, Adachi A, Terrin MM, Navarro MFL. Compressive and diametral tensile strength of glass ionomer cements. J Appl Oral Sci. 2004;12(4):344-8

4. Cacciafesta V, Sfondrini MF, Stifanelli P, Scribante A, Klersy C. Effect of chlorhexidine application on shear bond strength of brackets bonded with a resinmodified glass ionomer. Am J Orthod Dentofacial Orthop. 2003;129(2):273-6.

5. Gillgrass TJ, Benington PCM, Millett DT, Newell J, Gilmour WH. Modified composite or conventional glass ionomer for band cementation? A comparative clinical trial. Am J Orthod Dentofacial Orthop. 2001;120(1):49-53.

6. Gilgrass TJ, Millett DT, Creanor SL, Mackenzie D, Bagg J, Gilmour WH, et al. Fluoride release, microbial inhibition and microleakage pattern of two orthodontic band cements. J Dent. 1999;27(6):455-61.

7. Gladys S, Van Meerbeek B, Braem M, Lambrechts P, Vanherle G. Comparative physico-mechanical characterization of new hybrid restorative materials with conventional glass ionomer and resin composite restorative materials. J Dent Res. 1997;76(4):883-94.

8. Kleverlaan CJ, Van Duinen RNB, Feilzer AJ. Mechanical properties of glass ionomer cements affected by curing methods. Dent Mater. 2004;20(1):45-50.

9. Knox J, Chye KY, Durning P. An ex vivo evaluation of resin-modified glass polyalkenoates and polyacid-modified composite resins as orthodontic band cements. J Orthod. 2004;31(4):323-8

10. Liebmann SM, Jost-Brinkmann P. In vitro study of resin-modified glass ionomer cements for cementation of orthodontic bands. J Orofac Orthop. 1999;60(5):348-60.

11. Meehan MP, Foley TF, Mamandras AH. A comparison of the shear bond strengths of two glass ionomer cements. Am J Orthod Dentofacial Orthop. 1999;115(2):125-32.

12. Millett DT, Cummings A, Letters S, Roger E, Love J. Resin-modified glass ionomer, modified composite or conventional glass ionomer for band cementation? An in vitro evaluation. Eur J Orthod. 2003;25(6):609-14.

13. Millett DT, Duff S, Morrison L, Cummings A, Gilmour WH. In vitro comparison of orthodontic band cements. Am J Orthod Dentofacial Orthop. 2003;123(1):15-20.
14. Millett DT, Hallgren A, McCluskey LA, McAuley F, Fornell AC, Love J, et al. A clinical retrospective evaluation of 2 orthodontic band cements. Angle Orthod. 2001;71(6):470-6

15. Millett DT, Kamahli K, McColl J. Comparative laboratory investigation of dual-cured vs. Conventional glass ionomer cements for band cementation. Angle Orthod. 1998;68(4):345-50.

16. Mount GJ. Atlas de cimentos de ionômero de vidro. São Paulo: Ed. Santos; 1999.

17. Mudjeci A, Gokay O. Effect bleaching agents on the microhardness of toothcolored restorative materials. J Prost Dent. 2006;95(4):286-9.

18. Rezk-Lega F, Ogaard B, Arends J. An in vitro study on the merits of two glass ionomer for the cementation of orthodontic bands. Am J Orthod Dentofacial Orthop. 1991;99(4):162-7.

19. Seeholzer HW, Dasch W. Banding with glass ionomer cement. J Clin Orthod. 1988;22(3):165-9.

20. Sidhu SK, Watson TF. Resin-modified glass ionomer cement materials. Am J Dent. 1995;8(1):59-67.

21. Xu X, Burgess JO. Compressive strength, fluoride release and recharge of fluoridereleasing materials. Biomaterials. 2003;24(14):2451-61.

22. Wang L, D'Alpino PHP, Lopes LG, Pereira JC. Mechanical properties of dental restorative materials: relative contribution of laboratory tests. J Appl Oral Sci. 2003;11(3):162-7.

23. Weissheimer F, Marchioro EM, Dolci GS, Spohr AM. Novos materiais utilizados na cimentação de bandas ortodônticas. Ortodon Gaúch. 2005;9(1):23-8.

24. Weissheimer F, Marchioro EM, Dolci GS, Spohr AM, Hahn L. A influência do jateamento na cimentação de bandas ortodônticas. Rev Dental Press Ortod Ortop Facial. 2006;11(3):81-7.

25. White LW. Glass ionomer cement. J Clin Orthod. 1986;20(6):387-91.

26. Wilson AD. Resin-modified glass-ionomer cements. Int J Prosthodont. 1990;3(5):425-9.

27. Wilson $A D$, Kent BE. A new translucent cement for dentistry. Br Dental J. 1972;132(4):133-5.

28. Wilde MGK, Sassi JF, Garcia PPNS, Palma-Dibb RG. Influence of 0,05\% sodium fluoride solutions on microhardness of resin-modified glass ionomer cements. J Mater Sci Mater Med. 2006:17(9):869-73. 